\title{
Does Nut Consumption Reduce Mortality and/or Risk of Cardiometabolic Disease? An Updated Review Based on Meta-Analyses
}

\author{
Yoona Kim ${ }^{1}$, Jennifer B Keogh ${ }^{2} \mathbb{C}$ and Peter M Clifton ${ }^{2, *(1)}$ \\ 1 Department of Food and Nutrition/Institute of Agriculture and Life Science, Gyeongsang National \\ University, Jinju 52828, Korea; yoona.kim@gnu.ac.kr \\ 2 School of Pharmacy and Medical Sciences, University of South Australia, General Post Office Box 2471, \\ Adelaide, SA 5001, Australia; jennifer.keogh@unisa.edu.au \\ * Correspondence: peter.clifton@unisa.edu.au; Tel.: +61-8-8302-1357
}

Received: 13 November 2019; Accepted: 3 December 2019; Published: 6 December 2019

\begin{abstract}
Aim We aimed to determine if nut consumption decreases mortality and/or the risk of cardiometabolic diseases based on updated meta-analyses of epidemiological and intervention studies. Methods. An updated electronic search was conducted in PubMed/MEDLINE, Cumulative Index to Nursing and Allied Health Literature (CINAHL), and the Cochrane Library databases for original meta-analyses to investigate the effects of nut consumption on cardiometabolic disease in humans. Results. Seven new meta-analyses were included in this updated review. Findings similar to our previous review were observed, showing that nut consumption significantly decreased cardiovascular disease (CVD) mortality $(-19 \%$ to $-25 \% ; n=4)$, coronary heart disease (CHD) mortality $(-24 \%$ to $-30 \% ; n=3)$, stroke mortality $(-17 \%$ to $-18 \% ; n=3)$, CVD incidence $(-15 \%$ to $-19 \% ; n=4)$, CHD [or coronary artery disease (CAD)] incidence $(-17 \%$ to $-34 \% ; n=8)$, and stroke incidence $(-10 \%$ to $-11 \% ; n=6)$ comparing high with low categories of nut consumption. Fasting glucose levels $(0.08$ to $0.15 \mathrm{mmol} / \mathrm{L} ; n=6$ ), total cholesterol (TC; 0.021 to $0.30 \mathrm{mmol} / \mathrm{L} ; n=10)$, and low-density lipoprotein cholesterol (LDL-C; 0.017 to $0.26 \mathrm{mmol} / \mathrm{L} ; n=10$ ) were significantly decreased with nut consumption compared with control diets. Body weight and blood pressure were not significantly affected by nut consumption. Conclusion. Nut consumption appears to exert a protective effect on cardiometabolic disease, possibly through improved concentrations of fasting glucose, total cholesterol, and LDL-C.
\end{abstract}

Keywords: meta-analyses; nuts; cardiometabolic disease; low-density lipoprotein cholesterol; fasting blood glucose

\section{Introduction}

Nuts comprise $43-67 \%$ fat and $8-22 \%$ protein by weight. Nuts have unique nutritional profiles. Nuts are abundant in unsaturated fatty acids (UFAs) (containing both monounsaturated fatty acids (MUFAs) and polyunsaturated fatty acids (PUFAs)) and only $4-5 \%$ of saturated fatty acids (SFAs). Nuts are high in vitamins, minerals, fiber, and bioactive compounds, including carotenoids, phytosterols, and polyphenols [1,2].

As we suggested, for a potential mechanism of action of nuts [3], MUFAs and PUFAs are candidates for favorable glucose control and reduction of appetite. Arginine and magnesium can contribute to improved inflammation, oxidative stress, endothelial function, and blood pressure. Polyphenols can lower the risk of type 2 diabetes mellitus (T2DM). The suggested schematic figure showing metabolic effects and effects on clinical endpoints based on our previous publication [3] is briefly described in Figure 1. 


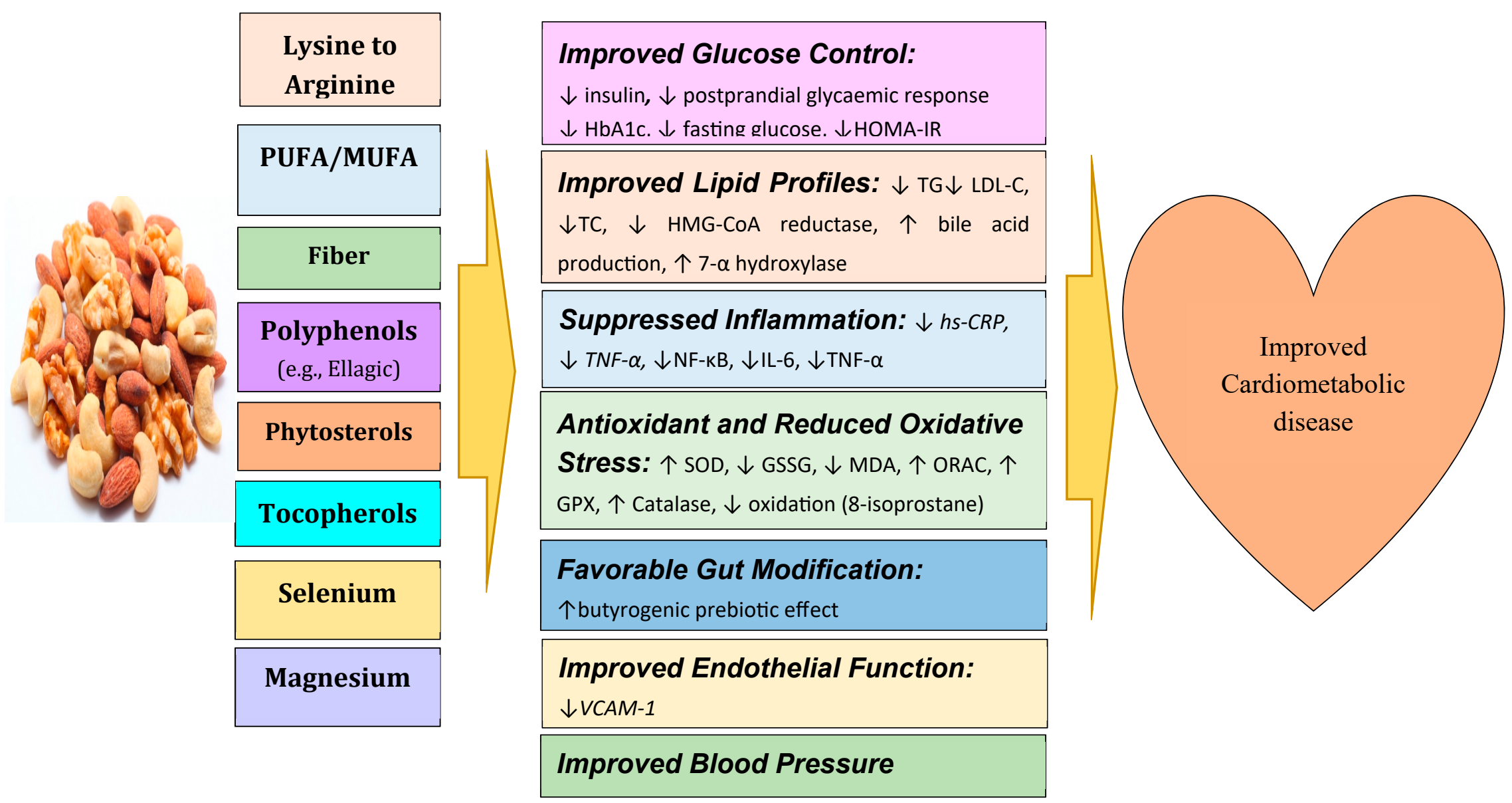

Figure 1. The summary of possible mechanisms linking nut consumption to improved cardiometabolic disease. CCK, cholecystokinin; GLP-1, glucagon-like peptide-1; GPx, Glutathione peroxidase; GSSG, oxidized glutathione; HbA1c, glycosylated hemoglobin; HOMA-IR, homeostasis model assessment of insulin resistance; hs-CRP, high sensitivity C-reactive protein; LDL-C, low density lipoprotein cholesterol; IL-6, interleukin-6; MDA, malondialdehyde; MUFA, monounsaturated fatty acid; ORAC, oxygen radical absorbance capacity; PUFA, polyunsaturated fatty acid; SOD, superoxide dismutase; TC, total cholesterol; TG, triglyceride; TNF $\alpha$, tumor necrosis factor alpha; VCAM-1, vascular cell adhesion molecule- 1 ; $\uparrow$, increase; $\downarrow$, decrease. 
As previously reported [4], nut consumption was inversely associated with all-cause mortality $(-19 \%$ to $-20 \% ; n=6)$, cardiovascular disease (CVD) mortality $(-25 \% ; n=3)$, coronary heart disease (CHD) mortality $(-27 \%$ to $-30 \% ; n=2)$, and stroke mortality $(-18 \% ; n=2)$. Moreover, nut consumption was associated with lowered risks of CVD $(-19 \% ; n=3)$, CHD $(-20 \%$ to $-34 \% ; n=2)$, stroke $(-10 \%$ to $-11 \% ; n=7)$, and hypertension $(-15 \% ; n=3)$ from meta-analyses of prospective studies. No effect of nut consumption on T2DM risk was observed in prospective studies, while significantly lowered fasting glucose levels $(-0.08$ to $-0.15 \mathrm{mmol} / \mathrm{L})$ were observed in meta-analyses of randomized control trials (RCTs). In meta-analyses of RCTs, decreases in total cholesterol (TC; $(-0.021$ to $-0.28 \mathrm{mmol} / \mathrm{L})$ and low-density lipoprotein cholesterol (LDL-C; -0.017 to $-0.26 \mathrm{mmol} / \mathrm{L}$ ) and improvements in endothelial function $(0.79 \%$ to $1.03 \%$ increase in flow-mediated dilation) were observed. No effects on body weight, inflammatory markers, and blood pressure were seen with nut consumption.

This review aims to update our previous review of meta-analyses in order to determine the effect of nut consumption on cardiometabolic disease.

\section{Materials and Methods}

The literature search was conducted in PubMed/MEDLINE, Cumulative Index to Nursing and Allied Health Literature (CINAHL), and the Cochrane Library databases, restricted to full articles investigating meta-analyses of the effects of nut consumption on cardiometabolic diseases in humans. Only research articles written in English up to 11 November 2019 were included. The search terms included meta-analysis combined with nut(s) or tree nut(s) or almond(s) or Brazil nut(s) or cashew nut(s) or hazelnut(s) or macadamia(s) or peanut(s) or pistachio(s) or walnut(s) or mortality or incidence or CVD or coronary heart disease (CHD) or stroke or T2DM or hypertension or metabolic syndrome or obesity or blood pressure or glycemic control or glucose or lipids or inflammatory markers or endothelial function and flow-mediated dilation. Reference lists of chosen articles were also screened for related publications. A previous review [4] examined 34 meta-analyses, and this review added 7 new meta-analyses [5-11]. A flow chart for the identified studies is included in this review in Figure 2.

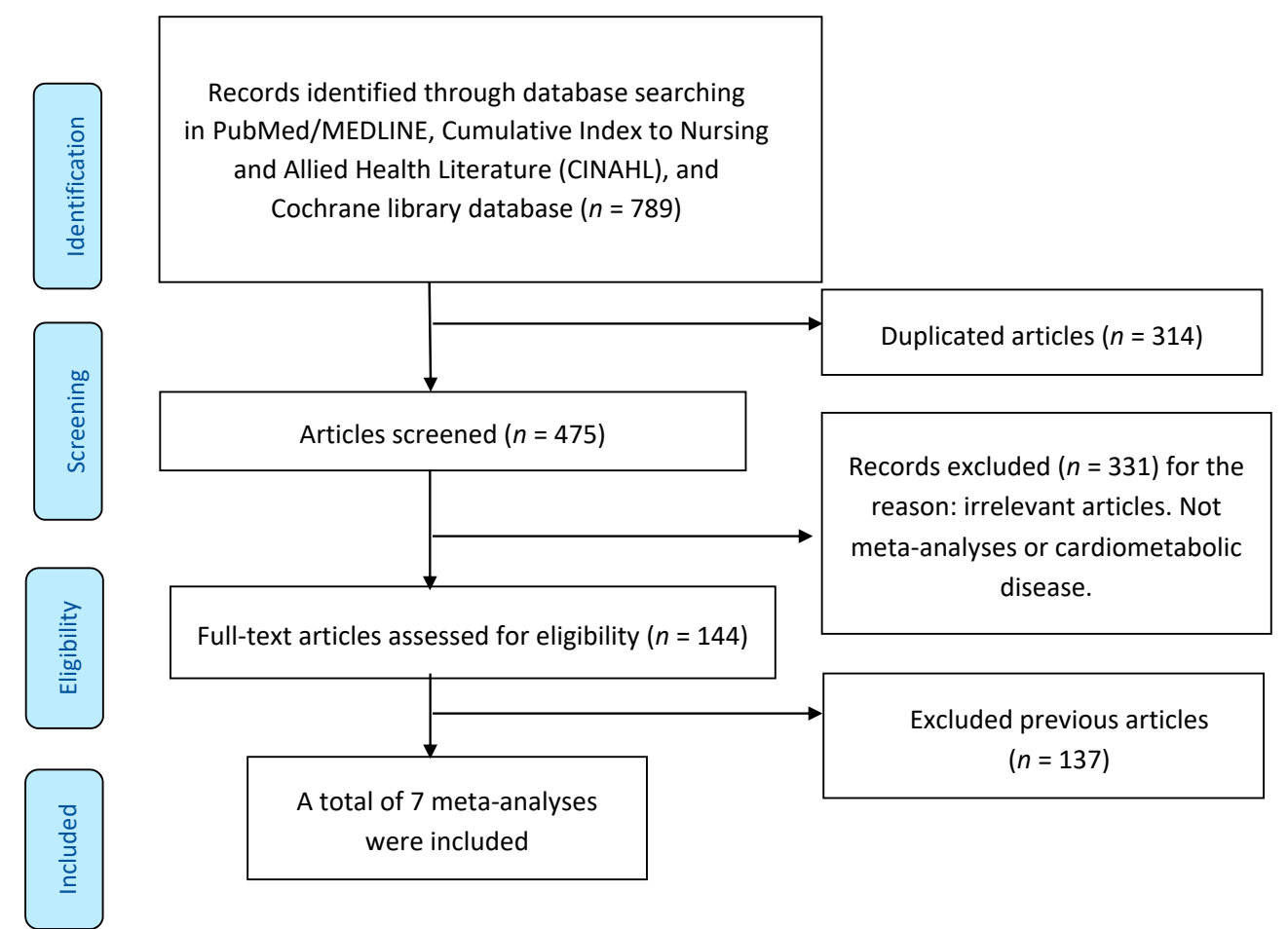

Figure 2. Flow diagram of the literature review. 


\section{Results}

\subsection{CVD Mortality}

In the present review, one meta-analysis of prospective studies conducted by Becerra-Tomas et al., 2019 [8] was included. They [8] showed nut consumption decreased CVD mortality (413,727 subjects and 14,475 cases) by $23 \%$ (relative risk $(\mathrm{RR})=0.77 ; 95 \%$ confidence interval $(\mathrm{CI}) 0.72,0.82 ; \mathrm{I}^{2}=3 \%$; $p_{\text {heterogeneity }}=0.42$ ) in a meta-analysis of 14 prospective studies (9 publications [12-20] comparing high vs low nut consumption categories). This reduction was similar to that shown in other meta-analyses. In the previous review [4], three meta-analyses [21-23] of prospective studies reported a 19-25\% lower rate of CVD mortality comparing the highest and lowest consumptions. A $19-25 \%$ reduction in CVD mortality was seen in these 4 meta-analyses [8,21-23].

\subsection{Coronary Heart Disease Mortality}

A previous review [4] reported a 27-30\% reduction in coronary heart disease (CHD) mortality from 2 meta-analyses of prospective studies [21,23]. When combined with the outcomes from a meta-analysis by Becerra-Tomas et al., 2019 [4], a reduction in CHD mortality ranged from $24 \%$ to $30 \%$.

Becerra-Tomas et al., 2019 [8] recently showed that nut consumption lowered CHD mortality $(396,041$ subjects and $7877 \mathrm{CHD}$ deaths $)$ by $24 \%\left(\mathrm{RR}=0.76 ; 95 \% \mathrm{CI} 0.67,0.86 ; \mathrm{I}^{2}=46 \%\right.$; $\left.p_{\text {heterogeneity }}=0.04\right)$ in a meta-analysis of 12 prospective studies (8 publications [12-15,19,24-26]) comparing high with low nut consumption categories. The meta-analysis of Chen et al., 2017 [23] included 13 studies (10 publications) [13-19,26-28].

\subsection{Stroke Mortality}

Becerra-Tomas et al., 2019 [8] showed a lower risk of stroke mortality (351,618 subjects and 2332 cases) following nut consumption with a RR of $0.83\left(95 \% \mathrm{CI} 0.75,0.93 ; \mathrm{I}^{2}=0 \%\right.$; $\left.p_{\text {heterogeneity }}=0.45\right)$ from a meta-analysis of 11 prospective studies (7 publications [12-14,18,19,26,29]) in a comparison of highest with lowest total nut consumption. This finding is consistent with the $18 \%$ reduction from 2 previous meta-analyses [21,23].

\subsection{Cardiovascular Disease Incidence}

A previous review [5] reported nut consumption reduced CVD incidence by $19 \%$ in 3 meta-analyses $[21,30,31]$ of prospective studies comparing high with low categories of nut consumption. When the recent meta-analysis by Becerra-Tomas et al., 2019 [8] was added [8,21,30,31], a similar reduction in incidence ranging from 15-19\% was observed. Becerra-Tomas et al., 2019 [8] showed that nut consumption lowered incidence of CVD by $15 \%\left(\mathrm{RR}=0.85 ; 95 \% \mathrm{CI} 0.80,0.91 ; \mathrm{I}^{2}=0 \%\right.$; $p_{\text {heterogeneity }}=0.81$ ) when 3 prospective studies (including the publication of Guasch-Ferre et al., 2017 [12]) from the Health Professionals Follow-up Study (HPFS), the Nurses' Health Study I (NHSI), and Nurses' Health Study II (NHSII) (210,836 subjects and 14,136 cases) were analyzed comparing $\geq 2$ servings/week versus never or almost never categories of nut consumption. However, peanut butter consumption was not associated with incidence of CVD (RR $=0.98 ; 95 \%$ CI 0.93, 1.03; $\mathrm{I}^{2}=89 \%$; $\left.p_{\text {heterogeneity }}<0.01\right)$. This publication [12] was only included by Becerra-Tomas et al., 2019 [8].

\subsection{Coronary Heart Disease Incidence}

A previous review [5] reported nut consumption decreased incidence of CHD (or CAD) by $17-34 \%$ in 7 meta-analyses [21,30-35] of prospective studies. When the meta-analysis by Becerra-Tomas et al., 2019 [8] was added [8,21,30-35], a 17-34\% reduction in CHD (or CAD) incidence was seen. Becerra-Tomas et al., 2019 [8] showed that nut consumption lowered incidence of CHD (275,812 subjects and 12,654 cases) by $18 \%\left(\mathrm{RR}=0.82 ; \mathrm{CI} 95 \% 0.69,0.96 ; \mathrm{I}^{2}=74 \%\right.$; $\left.p_{\text {heterogeneity }}<0.01\right)$ in 
a meta-analysis of 7 prospective studies (5 publications [12,24,25,36,37]) comparing high with low categories of nut consumption.

\subsection{Stroke Incidence}

A previous review [5] reported nut consumption reduced stroke incidence by $10-11 \%$ based on a meta-analysis of 10 studies (9 publications [13,14,19,26,29,38-41]) that was conducted by Aune et al., 2016 [22]. Their meta-analysis [22] had the greatest number of studies compared with other meta-analyses $[21,23,25,30]$. In this present review, we added a new meta-analysis conducted by Becerra-Tomas et al., 2019 [8]. They [8] showed that nut consumption was not associated with stroke incidence, but they only included 7 studies, so the findings of Aune are the most persuasive.

\subsection{Body Weight}

A previous review [5] reported no effect of nut consumption on body weight from 4 meta-analyses of prospective and intervention studies [42-45]. In this review, we included 3 more meta-analyses of observational and interventional studies [5-7]. As a result, nut consumption still did not significantly affect body weight based on 7 meta-analyses [5-7,42-45].

In a meta-analysis of 3 prospective studies [46-48] conducted by Schlesinger et al., 2019 [5], the association between nut consumption and the risk of overweight and obesity was found with an RR of 0.91 (95\% CI 0.80, 1.03; $\mathrm{I}^{2}=25 \%$ ) for the highest versus lowest nut consumption. The RR per $28 \mathrm{~g} / \mathrm{d}$ of nut consumption was $0.78\left(95 \% \mathrm{CI} 0.58,1.06 ; \mathrm{I}^{2}=64 \%\right)$.

\subsection{Randomized Controlled Trials}

Very recent meta-analysis of RCTs conducted by Akhlaghi et al., 2018 [6] reported a significantly suppressed hunger (mean difference $(\mathrm{MD})=-6.54 \mathrm{~mm}$ visual analogue scale (VAS); $95 \%$ CI 12.7, $0.42 \mathrm{~mm}$ VAS; $p=0.03$ ) from a meta-analysis of 14 RCTs (12 publications [49-60]). However, no association between nut consumption and fullness (MD = $0.03 \mathrm{~mm}$ VAS; 95\% CI 12.2, $12.3 \mathrm{~mm}$ VAS; $p=1$ ) was observed from a meta-analysis of 10 RCTs (9 publications [49-51,53-55,57,58,61]). No association between nut consumption and weight (MD $=0.09 \mathrm{~kg} ; 95 \%$ CI $0.59,0.41 \mathrm{~kg} ; p=0.72$ ) was observed from a meta-analysis of 15 RCTs (14 publications [49,53,58-60,62-70]).

Nut consumption increased energy intake (MD $=76.3 \mathrm{kcal} ; 95 \%$ CI 22.7, $130 \mathrm{kcal} ; p=0.005$ ) from a meta-analysis of 23 RCTs (21 publications [51,53,56,58-60,62-69,71-77]). Subanalysis showed that increased energy intake following nut consumption was observed only in overweight and obese subjects, not in normal weight subjects [6].

Lee-Bravatti et al., 2019 [7] conducted a meta-analysis of 11 RCTs [58,60,66,78-85] (432 subjects) and showed a significant decrease in body weight after almond consumption compared with control (summary net change: $-1.39 \mathrm{~kg} ; 95 \% \mathrm{CI}-2.49,-0.30 \mathrm{~kg} ; \mathrm{I}^{2}=0 \%, p_{\text {heterogeneity }}=0.87$ ). However, almond consumption did not affect body mass index (summary net change: $-0.33 \mathrm{~kg} ; 95 \% \mathrm{CI}-1.08,-0.43 \mathrm{~kg}$; $\mathrm{I}^{2}=21 \%$, $\left.p_{\text {heterogeneity }}=0.28\right)$, compared with controls from a meta-analysis of RCTs $[58,60,66,78,79,86]$.

\subsection{Glycemic Control}

In a previous review [5], nut consumption was found to decrease fasting glucose levels by 0.08 to $0.15 \mathrm{mmol} / \mathrm{L}$ compared with control diets based on 3 meta-analyses [87-89] of RCTs.

In this present review, we have included very recent meta-analyses conducted by Tindall et al., 2019 [9], Lee-Bravatti et al., 2019 [7], and Schwingshackl et al., 2018 [10].

Tindall et al., 2019 [9] found no association between nut consumption and fasting glucose (weighted mean difference (WMD) $\left.-0.52 \mathrm{mg} / \mathrm{dL}(0.028 \mathrm{mmol} / \mathrm{L}) ; 95 \% \mathrm{CI}-1.43,0.38 \mathrm{mg} / \mathrm{dL} ; \mathrm{I}^{2}=53.4 \%\right)$ from a meta-analysis of 39 RCTs [58,61,63,66-68,74,78,80,83,86,90-117]. Tindall et al., 2019 [9] found no effect of nut consumption on $\mathrm{HbA} 1 \mathrm{c}$ (WMD $0.02 \% ; 95 \% \mathrm{CI}-0.01 \%, 0.04 \% ; \mathrm{I}^{2}=51.0 \%$ ). Tindall et al., 2019 [9] observed significant reductions in homeostasis model assessment of insulin resistance (HOMA-IR) 
(WMD $-0.23 ; 95 \% \mathrm{CI}-0.40,-0.06 ; \mathrm{I}^{2}=51.7 \%$ ) and fasting insulin (WMD $-0.40 \mu \mathrm{IU} / \mathrm{mL} ; 95 \% \mathrm{CI}-0.73$, $-0.07 \mu \mathrm{IU} / \mathrm{mL} ; \mathrm{I}^{2}=49.4 \%$ ) after nut consumption from meta-analyses of 19 RCTs $[61,66,68,74,86,91,92$, 96,97,99,100,103-105,107,109,110,114,117] and 28 RCTs [58,61,63,66-68,74,86,91-93,95-97,99-105,107, 110,112-114,116,117], respectively.

Lee-Bravatti et al., 2019 [7] conducted a meta-analysis of 9 RCTs [58,66,78-80,82,83,86,102] and showed no effect of almond consumption on fasting blood glucose compared with control, and only subjects with CVD risk at baseline showed significant reduction (net change $-6.08 \mathrm{mg} / \mathrm{dL} ; 95 \% \mathrm{CI}$ $-10.77,-1.40 \mathrm{mg} / \mathrm{dL} ; \mathrm{I}^{2}=0 \%, p_{\text {heterogeneity }}=0.94$ ) at $>42.5 \mathrm{~g}$ almond consumption (summary net change $-4.11 \mathrm{mg} / \mathrm{dL} ; 95 \% \mathrm{CI}-7.43,-0.80 \mathrm{mg} / \mathrm{dL} ; \mathrm{I}^{2}=34 \%$, $\left.p_{\text {heterogeneity }}=0.19\right)$ compared with controls.

Schwingshackl et al., 2018 [10] conducted a network meta-analysis of 66 RCTs (86 publications with a total of 3595 subjects ( 280 subjects with T2DM)). They reported nuts are the best food group to lower fasting blood glucose $(-0.43,-0.35 \mathrm{mmol} / \mathrm{L})$, compared with refined grains and whole grains.

A meta-analysis by Mazidi et al., 2016 [87] that included 20 RCTs [59,68,74,81,96,98,100,109,110,112, 117-126], and a meta-analysis by Mejia et al., 2014 [89] that included 26 RCTs (healthy subjects [83,117] and subjects with dyslipidemia [65,126], metabolic syndrome [58,66,68,95,99,101,113,116,127-129], and T2DM $[86,93,94,102,103,112,114,130-132])$ showed a $0.08 \mathrm{mml} / \mathrm{L}$ reduction in fasting glucose. A meta-analysis of 12 RCTs $(n=450)$ by Viguiliouk et al., 2014 [88] showed a $0.15 \mathrm{mmol} / \mathrm{L}$ reduction of fasting glucose only in subjects with T2DM.

Overall, nut consumption appears to decrease fasting glucose levels by 0.08 to $0.15 \mathrm{mmol} / \mathrm{L}$ compared with control diets.

\subsection{Blood Lipids}

In a previous review [5], nut consumption had been reported to reduce total cholesterol (TC; 0.021 to $0.28 \mathrm{mmol} / \mathrm{L})$ and LDL-C ( 0.017 to $0.26 \mathrm{mmol} / \mathrm{L})$ compared with control diets from 8 metaanalyses [43,44,87,133-137].

In this present review, we included a meta-analysis conducted by Schwingshackl et al., 2018 [10] and Lee-Bravatti et al., 2019 [7].

In a network meta-analysis of 66 RCTs ( 86 publications with a total of 3595 subjects ( 280 subjects with T2DM)), Schwingshackl et al., 2018 [10] reported nuts are the best food group in lowering LDL-C $(-0.34$ to $-0.24 \mathrm{mg} / \mathrm{dL}(0.0088$ to $0.0062 \mathrm{mmol} / \mathrm{L}))$ and TC $(-0.39--0.30 \mathrm{mmol} / \mathrm{L})$ compared with legumes and whole grains.

Lee-Bravatti et al., 2019 [7] found significant reductions in TC (summary net change $=-10.69 \mathrm{mg} / \mathrm{dL}$ $\left.(0.276 \mathrm{mmol} / \mathrm{L}) ; 95 \% \mathrm{CI}-16.75,-4.63 \mathrm{mg} / \mathrm{dL} ; \mathrm{I}^{2}=67 \% ; p<0.01\right)$ and LDL-C (summary net change $=-5.38$ $\left.\mathrm{mg} / \mathrm{dL}(0.139 \mathrm{mmol} / \mathrm{L}) ; 95 \% \mathrm{CI}-9.91,-1.75 \mathrm{mg} / \mathrm{dL} ; \mathrm{I}^{2}=61 \% ; p<0.001\right)$ with almond consumption in a meta-analysis of 13 RCTs from 14 publications [58,66,78-83,85,86,102,138-140] including 491 subjects. They [7] observed no difference in triglyceride (TG) levels (summary net change $=-11.63 \mathrm{mg} / \mathrm{dL}$ $\left.(0.1313 \mathrm{mmol} / \mathrm{L}) ; 95 \% \mathrm{CI}-23.47,-0.21 \mathrm{mg} / \mathrm{dL} ; \mathrm{I}^{2}=71 \% ; p<0.01\right)$ following almond consumption compared with controls in a meta-analysis of 12 RCTs from 12 publications $[58,66,78-83,86,102,138]$ including 461 subjects.

Overall, nut consumption lowers total cholesterol (TC; 0.021 to $0.30 \mathrm{mmol} / \mathrm{L}$ ) and low-density lipoprotein cholesterol (LDL-C; 0.017 to $0.26 \mathrm{mmol} / \mathrm{L}$ ) compared with control diets in 10 metaanalyses [7,10,43,44,87,133-137].

\subsection{Blood Pressure}

A previous review [5] showed no effect of nut consumption on blood pressure from meta-analyses of RCTs. In this review, we included a recent meta-analysis conducted by Lee-Bravatti et al., 2019 [7]. They [7] showed no difference (summary net change: $-1.51 \mathrm{~mm} \mathrm{Hg}$; $95 \% \mathrm{CI}-3.96,-0.94 \mathrm{~mm} \mathrm{Hg}$; $\mathrm{I}^{2}=49 \%$, $p_{\text {heterogeneity }}=0.08$ ) between almond consumption and control for diastolic blood pressure (DBP) in the main meta-analysis of RCTs [58,66,78-81,86], but they found a significant reduction for $>42.5 \mathrm{~g}$ almond consumption (summary net change: $-3.15 \mathrm{mmHg}$; $95 \% \mathrm{CI}-5.77,-0.54 \mathrm{~mm} \mathrm{Hg}$; 
$\mathrm{I}^{2}=35 \%, p_{\text {heterogeneity }}=0.21$ ) and $>6$ weeks (summary net change: $-4.24 \mathrm{~mm} \mathrm{Hg} ; \mathrm{CI} 95 \%-6.68,-1.81$ $\mathrm{mm} \mathrm{Hg} ; \mathrm{I}^{2}=0 \%$, $p_{\text {heterogeneity }}=0.51$ ). Lee-Bravatti et al., 2019 [7] showed no difference between almond consumption and control for systolic blood pressure (SBP) (summary net change: $1.27 \mathrm{~mm}$ $\mathrm{Hg} ; 95 \% \mathrm{CI}-2.63,5.18 \mathrm{~mm} \mathrm{Hg} \mathrm{I}^{2}=51 \%$, pheterogeneity $=0.07$ ) in summary estimates with almond RCTs $[58,66,78,80,81,86,114]$ compared with control in either the main analysis or subgroup analyses.

\subsection{Metabolic Syndrome}

Zhang et al., 2019 [11] conducted a meta-analysis of 11 observational studies (6 cross-sectional [140-145] and 5 prospective studies [146-150]). They found that nut consumption was inversely associated with the risk of metabolic syndrome with RR of 0.84 (95\% CI 0.76, 0.92; $p<0.001 ; \mathrm{I}^{2}=79.5 \%$; $p_{\text {heterogeneity }}<$ $0.001)$. A subgroup analysis showed this inverse association was only present in tree nuts $(\mathrm{RR}=0.97$; $95 \%$ CI $0.94,1.00 ; p=0.04)$ but not in peanuts $(\mathrm{RR}=1.01 ; 95 \%$ CI $0.96,1.06 ; p=0.68)$.

\section{Discussion}

This present review is an updated review of meta-analyses that adds seven more recent meta-analyses aiming to clarify the effect of nut consumption on cardiometabolic disease. We found similar outcomes to our previous review when we combined new and previous meta-analyses investigating CVD mortality, CHD mortality, stroke mortality, CVD incidence, CHD (or CAD) incidence, and stroke incidence. In meta-analyses of interventions, nut consumption significantly reduced fasting glucose levels, TC, and LDL-C compared with controls. However, body weight and blood pressure did not differ after nut consumption compared with controls.

Schwingshackl et al., 2018 [10] showed the beneficial effect of nut consumption in a network meta-analysis of 66 RCTs ( 86 publications with a total of 3595 subjects (280 subjects with T2DM)). Nuts ranked highest for LDL-C, TG, TC, HDL-C, fasting blood glucose, HbA1c, SBP, DBP, and C-reactive protein (CRP), in comparison with other food groups, including legumes, whole grains, fish, fruits and vegetables, refined grains, red meat, eggs, dairy, and sugar-sweetened beverages [10]. Clearly, nut consumption appears to decrease cardiometabolic risks.

The results from this present review suggest there needs to be further large clinical trials testing nuts as therapeutic agents for primary and secondary prevention of cardiovascular disease.

\section{Conclusions}

This updated review of meta-analyses found that nut consumption has beneficial effects on cardiometabolic disease with reduced CVD mortality, CHD mortality, stroke mortality, CVD incidence, $\mathrm{CHD}$ incidence and stroke incidence comparing high with low categories of nut consumption. It may be attributable to decreases in fasting glucose, total cholesterol and LDL-C.

Author Contributions: All authors conceived of the manuscript structure and contributed to the writing and editing. Conceptualization, Y.K. and P.M.C.; Methodology, Y.K. and P.M.C.; Validation, Y.K. and P.M.C.; Formal Analysis, Y.K.; Investigation, Y.K. and P.M.C.; Resources, Y.K.; Data Curation, Y.K. and P.M.C.; Writing-Original Draft Preparation, Y.K.; Writing—Review \& Editing, J.B.K. and P.M.C.; Visualization, Y.K.; Supervision, P.M.C.; Project Administration, P.M.C.

Funding: This research received no external funding.

Conflicts of Interest: The authors declare no conflicts of interest related to this manuscript.

\section{References}

1. Alasalvar, C.; Bolling, B.W. Review of nut phytochemicals, fat-soluble bioactives, antioxidant components and health effects. Br. J. Nutr. 2015, 113, S68-S78. [CrossRef] [PubMed]

2. Venkatachalam, M.; Sathe, S.K. Chemical composition of selected edible nut seeds. J. Agric. Food Chem. 2006, 54, 4705-4714. [CrossRef] [PubMed]

3. Kim, Y.; Keogh, J.B.; Clifton, P.M. Benefits of Nut Consumption on Insulin Resistance and Cardiovascular Risk Factors: Multiple Potential Mechanisms of Actions. Nutrients 2017, 9, 1271. [CrossRef] [PubMed] 
4. Kim, Y.; Keogh, J.; Clifton, P.M. Nuts and Cardio-Metabolic Disease: A Review of Meta-Analyses. Nutrients 2018, 10, 1935. [CrossRef] [PubMed]

5. Schlesinger, S.; Neuenschwander, M.; Schwedhelm, C.; Hoffmann, G.; Bechthold, A.; Boeing, H.; Schwingshackl, L. Food Groups and Risk of Overweight, Obesity, and Weight Gain: A Systematic Review and Dose-Response Meta-Analysis of Prospective Studies. Adv. Nutr. 2019, 10, 205-218. [CrossRef]

6. Akhlaghi, M.; Ghobadi, S.; Zare, M.; Foshati, S. Effect of nuts on energy intake, hunger, and fullness, a systematic review and meta-analysis of randomized clinical trials. Crit. Rev. Food Sci. Nutr. 2018, 1-10. [CrossRef]

7. Lee-Bravatti, M.A.; Wang, J.; Avendano, E.E.; King, L.; Johnson, E.J.; Raman, G. Almond Consumption and Risk Factors for Cardiovascular Disease: A Systematic Review and Meta-analysis of Randomized Controlled Trials. Adv. Nutr. 2019. [CrossRef]

8. Becerra-Tomas, N.; Paz-Graniel, I.; WC Kendall, C.; Kahleova, H.; Rahelic, D.; Sievenpiper, J.L.; Salas-Salvado, J. Nut consumption and incidence of cardiovascular diseases and cardiovascular disease mortality: A meta-analysis of prospective cohort studies. Nutr. Rev. 2019, 77, 691-709. [CrossRef]

9. Tindall, A.M.; Johnston, E.A.; Kris-Etherton, P.M.; Petersen, K.S. The effect of nuts on markers of glycemic control: A systematic review and meta-analysis of randomized controlled trials. Am. J. Clin. Nutr. 2019, 109, 297-314. [CrossRef]

10. Schwingshackl, L.; Hoffmann, G.; Iqbal, K.; Schwedhelm, C.; Boeing, H. Food groups and intermediate disease markers: A systematic review and network meta-analysis of randomized trials. Am. J. Clin. Nutr. 2018, 108, 576-586. [CrossRef]

11. Zhang, Y.; Zhang, D.Z. Relationship Between Nut Consumption and Metabolic Syndrome: A Meta-Analysis of Observational Studies. J. Am. Coll. Nutr. 2019, 38, 499-505. [CrossRef] [PubMed]

12. Guasch-Ferre, M.; Liu, X.; Malik, V.S.; Sun, Q.; Willett, W.C.; Manson, J.E.; Rexrode, K.M.; Li, Y.; Hu, F.B.; Bhupathiraju, S.N. Nut Consumption and Risk of Cardiovascular Disease. J. Am. Coll. Cardiol. 2017, 70, 2519-2532. [CrossRef] [PubMed]

13. van den Brandt, P.A.; Schouten, L.J. Relationship of tree nut, peanut and peanut butter intake with total and cause-specific mortality: A cohort study and meta-analysis. Int. J. Epidemiol. 2015, 44, 1038-1049. [CrossRef] [PubMed]

14. Luu, H.N.; Blot, W.J.; Xiang, Y.B.; Cai, H.; Hargreaves, M.K.; Li, H.; Yang, G.; Signorello, L.; Gao, Y.T.; Zheng, W.; et al. Prospective evaluation of the association of nut/peanut consumption with total and cause-specific mortality. JAMA Intern. Med. 2015, 175, 755-766. [CrossRef] [PubMed]

15. Blomhoff, R.; Carlsen, M.H.; Andersen, L.F.; Jacobs, D.R., Jr. Health benefits of nuts: Potential role of antioxidants. Br. J. Nutr. 2006, 96 (Suppl. S2), S52-S60. [CrossRef] [PubMed]

16. Bao, Y.; Han, J.; Hu, F.B.; Giovannucci, E.L.; Stampfer, M.J.; Willett, W.C.; Fuchs, C.S. Association of nut consumption with total and cause-specific mortality. N. Engl. 2013, 369, 2001-2011. [CrossRef]

17. Guasch-Ferre, M.; Bullo, M.; Martinez-Gonzalez, M.A.; Ros, E.; Corella, D.; Estruch, R.; Fito, M.; Aros, F.; Warnberg, J.; Fiol, M.; et al. Frequency of nut consumption and mortality risk in the PREDIMED nutrition intervention trial. BMC Med. 2013, 11, 164. [CrossRef]

18. Hshieh, T.T.; Petrone, A.B.; Gaziano, J.M.; Djousse, L. Nut consumption and risk of mortality in the Physicians' Health Study. Am. J. Clin. Nutr. 2015, 101, 407-412. [CrossRef]

19. Bonaccio, M.; Di Castelnuovo, A.; De Curtis, A.; Costanzo, S.; Bracone, F.; Persichillo, M.; Donati, M.B.; de Gaetano, G.; Iacoviello, L. Nut consumption is inversely associated with both cancer and total mortality in a Mediterranean population: Prospective results from the Moli-sani study. Br. J. Nutr. 2015, 114, 804-811. [CrossRef]

20. Eslamparast, T.; Sharafkhah, M.; Poustchi, H.; Hashemian, M.; Dawsey, S.M.; Freedman, N.D.; Boffetta, P.; Abnet, C.C.; Etemadi, A.; Pourshams, A.; et al. Nut consumption and total and cause-specific mortality: Results from the Golestan Cohort Study. Int. J. Epidemiol. 2017, 46, 75-85. [CrossRef]

21. Mayhew, A.J.; de Souza, R.J.; Meyre, D.; Anand, S.S.; Mente, A. A systematic review and meta-analysis of nut consumption and incident risk of CVD and all-cause mortality. Br. J. Nutr. 2016, 115, 212-225. [CrossRef] [PubMed]

22. Grosso, G.; Yang, J.; Marventano, S.; Micek, A.; Galvano, F.; Kales, S.N. Nut consumption on all-cause, cardiovascular, and cancer mortality risk: A systematic review and meta-analysis of epidemiologic studies. Am. J. Clin. Nutr. 2015, 101, 783-793. [CrossRef] [PubMed] 
23. Chen, G.C.; Zhang, R.; Martinez-Gonzalez, M.A.; Zhang, Z.L.; Bonaccio, M.; van Dam, R.M.; Qin, L.Q. Nut consumption in relation to all-cause and cause-specific mortality: A meta-analysis 18 prospective studies. Food Funct. 2017, 8, 3893-3905. [CrossRef] [PubMed]

24. Larsson, S.C.; Drca, N.; Bjorck, M.; Back, M.; Wolk, A. Nut consumption and incidence of seven cardiovascular diseases. Heart 2018, 104, 1615-1620. [CrossRef] [PubMed]

25. Albert, C.M.; Gaziano, J.M.; Willett, W.C.; Manson, J.E. Nut consumption and decreased risk of sudden cardiac death in the Physicians' Health Study. Arch. Intern. Med. 2002, 162, 1382-1387. [CrossRef]

26. Gopinath, B.; Flood, V.M.; Burlutksy, G.; Mitchell, P. Consumption of nuts and risk of total and cause-specific mortality over 15 years. Nutr. Metab. Cardiovasc. Dis. 2015, 25, 1125-1131. [CrossRef]

27. Fraser, G.E.; Shavlik, D.J. Risk factors for all-cause and coronary heart disease mortality in the oldest-old. The Adventist Health Study. Arch. Intern. Med. 1997, 157, 2249-2258. [CrossRef]

28. Mann, J.I.; Appleby, P.N.; Key, T.J.; Thorogood, M. Dietary determinants of ischaemic heart disease in health conscious individuals. Heart 1997, 78, 450-455. [CrossRef]

29. di Giuseppe, R.; Fjeld, M.K.; Dierkes, J.; Theoflylaktopoulou, D.; Arregui, M.; Boeing, H.; Weikert, C. The association between nut consumption and the risk of total and ischemic stroke in a German cohort study. Eur. J. Clin. Nutr. 2015, 69, 431-435. [CrossRef]

30. Luo, C.; Zhang, Y.; Ding, Y.; Shan, Z.; Chen, S.; Yu, M.; Hu, F.B.; Liu, L. Nut consumption and risk of type 2 diabetes, cardiovascular disease, and all-cause mortality: A systematic review and meta-analysis. Am. J. Clin. Nutr. 2014, 100, 256-269. [CrossRef]

31. Aune, D.; Keum, N.; Giovannucci, E.; Fadnes, L.T.; Boffetta, P.; Greenwood, D.C.; Tonstad, S.; Vatten, L.J.; Riboli, E.; Norat, T. Nut consumption and risk of cardiovascular disease, total cancer, all-cause and cause-specific mortality: A systematic review and dose-response meta-analysis of prospective studies. BMC Med. 2016, 14, 207. [CrossRef] [PubMed]

32. Bechthold, A.; Boeing, H.; Schwedhelm, C.; Hoffmann, G.; Knuppel, S.; Iqbal, K.; De Henauw, S.; Michels, N.; Devleesschauwer, B.; Schlesinger, S.; et al. Food groups and risk of coronary heart disease, stroke and heart failure: A systematic review and dose-response meta-analysis of prospective studies. Crit. Rev. Food Sci. Nutr. 2017, 1-20. [CrossRef] [PubMed]

33. Weng, Y.Q.; Yao, J.; Guo, M.L.; Qin, Q.J.; Li, P. Association between nut consumption and coronary heart disease: A meta-analysis. Coron. Artery Dis. 2016, 27, 227-232. [CrossRef] [PubMed]

34. Zhou, D.; Yu, H.; He, F.; Reilly, K.H.; Zhang, J.; Li, S.; Zhang, T.; Wang, B.; Ding, Y.; Xi, B. Nut consumption in relation to cardiovascular disease risk and type 2 diabetes: A systematic review and meta-analysis of prospective studies. Am. J. Clin. Nutr. 2014, 100, 270-277. [CrossRef] [PubMed]

35. Ma, L.; Wang, F.; Guo, W.; Yang, H.; Liu, Y.; Zhang, W. Nut consumption and the risk of coronary artery disease: A dose-response meta-analysis of 13 prospective studies. Thromb. Res. 2014, 134, 790-794. [CrossRef] [PubMed]

36. Fraser, G.E.; Sabate, J.; Beeson, W.L.; Strahan, T.M. A possible protective effect of nut consumption on risk of coronary heart disease. The Adventist Health Study. Arch. Intern. Med. 1992, 152, 1416-1424. [CrossRef]

37. Haring, B.; Gronroos, N.; Nettleton, J.A.; von Ballmoos, M.C.; Selvin, E.; Alonso, A. Dietary protein intake and coronary heart disease in a large community based cohort: Results from the Atherosclerosis Risk in Communities (ARIC) study [corrected]. PLoS ONE 2014, 9, e109552. [CrossRef]

38. Haring, B.; Misialek, J.R.; Rebholz, C.M.; Petruski-Ivleva, N.; Gottesman, R.F.; Mosley, T.H.; Alonso, A. Association of Dietary Protein Consumption With Incident Silent Cerebral Infarcts and Stroke: The Atherosclerosis Risk in Communities (ARIC) Study. Stroke 2015, 46, 3443-3450. [CrossRef]

39. Bernstein, A.M.; Pan, A.; Rexrode, K.M.; Stampfer, M.; Hu, F.B.; Mozaffarian, D.; Willett, W.C. Dietary protein sources and the risk of stroke in men and women. Stroke 2012, 43, 637-644. [CrossRef]

40. Djousse, L.; Gaziano, J.M.; Kase, C.S.; Kurth, T. Nut consumption and risk of stroke in US male physicians. Clin. Nutr. 2010, 29, 605-609. [CrossRef]

41. Yochum, L.A.; Folsom, A.R.; Kushi, L.H. Intake of antioxidant vitamins and risk of death from stroke in postmenopausal women. Am. J. Clin. Nutr. 2000, 72, 476-483. [CrossRef] [PubMed]

42. Li, H.; Li, X.; Yuan, S.; Jin, Y.; Lu, J. Nut consumption and risk of metabolic syndrome and overweight/obesity: A meta-analysis of prospective cohort studies and randomized trials. Nutr. Metab. 2018, 15, 46. [CrossRef] [PubMed] 
43. Guasch-Ferre, M.; Li, J.; Hu, F.B.; Salas-Salvado, J.; Tobias, D.K. Effects of walnut consumption on blood lipids and other cardiovascular risk factors: An updated meta-analysis and systematic review of controlled trials. Am. J. Clin. Nutr. 2018, 108, 174-187. [CrossRef] [PubMed]

44. Banel, D.K.; Hu, F.B. Effects of walnut consumption on blood lipids and other cardiovascular risk factors: A meta-analysis and systematic review. Am. J. Clin. Nutr. 2009, 90, 56-63. [CrossRef]

45. Flores-Mateo, G.; Rojas-Rueda, D.; Basora, J.; Ros, E.; Salas-Salvado, J. Nut intake and adiposity: Meta-analysis of clinical trials. Am. J. Clin. Nutr. 2013, 97, 1346-1355. [CrossRef]

46. Bes-Rastrollo, M.; Sabate, J.; Gomez-Gracia, E.; Alonso, A.; Martinez, J.A.; Martinez-Gonzalez, M.A. Nut consumption and weight gain in a Mediterranean cohort: The SUN study. Obesity 2007, 15, 107-116. [CrossRef]

47. Bes-Rastrollo, M.; Wedick, N.M.; Martinez-Gonzalez, M.A.; Li, T.Y.; Sampson, L.; Hu, F.B. Prospective study of nut consumption, long-term weight change, and obesity risk in women. Am. J. Clin. Nutr. 2009, 89, 1913-1919. [CrossRef]

48. Freisling, H.; Noh, H.; Slimani, N.; Chajes, V.; May, A.M.; Peeters, P.H.; Weiderpass, E.; Cross, A.J.; Skeie, G.; Jenab, M.; et al. Nut intake and 5-year changes in body weight and obesity risk in adults: Results from the EPIC-PANACEA study. Eur. J. Nutr. 2018, 57, 2399-2408. [CrossRef]

49. Alves, R.D.; Moreira, A.P.; Macedo, V.S.; de Cassia Goncalves Alfenas, R.; Bressan, J.; Mattes, R.; Costa, N.M. Regular intake of high-oleic peanuts improves fat oxidation and body composition in overweight/obese men pursuing a energy-restricted diet. Obesity 2014, 22, 1422-1429. [CrossRef]

50. Barbour, J.A.; Howe, P.R.; Buckley, J.D.; Wright, G.C.; Bryan, J.; Coates, A.M. Lower energy intake following consumption of Hi-oleic and regular peanuts compared with iso-energetic consumption of potato crisps. Appetite 2014, 82, 124-130. [CrossRef]

51. Burton-Freeman, B. Sex and cognitive dietary restraint influence cholecystokinin release and satiety in response to preloads varying in fatty acid composition and content. J. Nutr. 2005, 135, 1407-1414. [CrossRef] [PubMed]

52. Casas-Agustench, P.; Lopez-Uriarte, P.; Bullo, M.; Ros, E.; Gomez-Flores, A.; Salas-Salvado, J. Acute effects of three high-fat meals with different fat saturations on energy expenditure, substrate oxidation and satiety. Clin. Nutr. 2009, 28, 39-45. [CrossRef] [PubMed]

53. Dhillon, J.; Tan, S.Y.; Mattes, R.D. Almond Consumption during Energy Restriction Lowers Truncal Fat and Blood Pressure in Compliant Overweight or Obese Adults. Nutr. J. 2016, 146, 2513-2519. [CrossRef] [PubMed]

54. Hull, S.; Re, R.; Chambers, L.; Echaniz, A.; Wickham, M.S. A mid-morning snack of almonds generates satiety and appropriate adjustment of subsequent food intake in healthy women. Eur. J. Nutr. 2015, 54, 803-810. [CrossRef] [PubMed]

55. Duarte Moreira Alves, R.; Boroni Moreira, A.P.; Silva Macedo, V.; Brunoro Costa, N.M.; Goncalves Alfenas Rde, C.; Bressan, J. High-oleic peanuts increase diet-induced thermogenesis in overweight and obese men. Nutr. Hosp. 2014, 29, 1024-1032. [CrossRef]

56. Kirkmeyer, S.V.; Mattes, R.D. Effects of food attributes on hunger and food intake. Int. J. Obes. 2000, 24, 1167-1175. [CrossRef]

57. Sayer, R.D.; Dhillon, J.; Tamer, G.G.; Cornier, M.A.; Chen, N.; Wright, A.J.; Campbell, W.W.; Mattes, R.D. Consuming Almonds vs. Isoenergetic Baked Food Does Not Differentially Influence Postprandial Appetite or Neural Reward Responses to Visual Food Stimuli. Nutrients 2017, 9, 807. [CrossRef]

58. Tan, S.Y.; Mattes, R.D. Appetitive, dietary and health effects of almonds consumed with meals or as snacks: A randomized, controlled trial. Eur. J. Clin. Nutr. 2013, 67, 1205-1214. [CrossRef]

59. Tey, S.L.; Gray, A.R.; Chisholm, A.W.; Delahunty, C.M.; Brown, R.C. The dose of hazelnuts influences acceptance and diet quality but not inflammatory markers and body composition in overweight and obese individuals. Nutr. J. 2013, 143, 1254-1262. [CrossRef]

60. Zaveri, S.; Drummond, S. The effect of including a conventional snack (cereal bar) and a nonconventional snack (almonds) on hunger, eating frequency, dietary intake and body weight. J. Hum. Nutr. Diet. 2009, 22, 461-468. [CrossRef]

61. Rock, C.L.; Flatt, S.W.; Pakiz, B.; Quintana, E.L.; Heath, D.D.; Rana, B.K.; Natarajan, L. Effects of diet composition on weight loss, metabolic factors and biomarkers in a 1-year weight loss intervention in obese women examined by baseline insulin resistance status. Metabolism 2016, 65, 1605-1613. [CrossRef] [PubMed] 
62. Liu, Y.; Hwang, H.J.; Kim, H.S.; Park, H. Time and Intervention Effects of Daily Almond Intake on the Changes of Lipid Profile and Body Composition Among Free-Living Healthy Adults. J. Med. Food 2018, 21, 340-347. [CrossRef]

63. Agebratt, C.; Strom, E.; Romu, T.; Dahlqvist-Leinhard, O.; Borga, M.; Leandersson, P.; Nystrom, F.H. A Randomized Study of the Effects of Additional Fruit and Nuts Consumption on Hepatic Fat Content, Cardiovascular Risk Factors and Basal Metabolic Rate. PLoS ONE 2016, 11, e0147149. [CrossRef] [PubMed]

64. Claesson, A.L.; Holm, G.; Ernersson, A.; Lindstrom, T.; Nystrom, F.H. Two weeks of overfeeding with candy, but not peanuts, increases insulin levels and body weight. Scand. J. Clin. Lab. Investig. 2009, 69, 598-605. [CrossRef]

65. Jenkins, D.J.; Kendall, C.W.; Marchie, A.; Josse, A.R.; Nguyen, T.H.; Faulkner, D.A.; Lapsley, K.G.; Blumberg, J. Almonds reduce biomarkers of lipid peroxidation in older hyperlipidemic subjects. J. Nutr. 2008, 138, 908-913. [CrossRef] [PubMed]

66. Wien, M.; Bleich, D.; Raghuwanshi, M.; Gould-Forgerite, S.; Gomes, J.; Monahan-Couch, L.; Oda, K. Almond consumption and cardiovascular risk factors in adults with prediabetes. Am. J. Coll. Nutr. 2010, 29, 189-197. [CrossRef]

67. Johnston, C.S.; Trier, C.M.; Fleming, K.R. The effect of peanut and grain bar preloads on postmeal satiety, glycemia, and weight loss in healthy individuals: An acute and a chronic randomized intervention trial. J. Nutr. 2013, 12, 35. [CrossRef]

68. Casas-Agustench, P.; Lopez-Uriarte, P.; Bullo, M.; Ros, E.; Cabre-Vila, J.J.; Salas-Salvado, J. Effects of one serving of mixed nuts on serum lipids, insulin resistance and inflammatory markers in patients with the metabolic syndrome. Nutr. Metab. Cardiovasc. Dis. 2011, 21, 126-135. [CrossRef]

69. Neale, E.P.; Tapsell, L.C.; Martin, A.; Batterham, M.J.; Wibisono, C.; Probst, Y.C. Impact of providing walnut samples in a lifestyle intervention for weight loss: A secondary analysis of the HealthTrack trial. Food Nutr. Res. 2017, 61, 1344522. [CrossRef] [PubMed]

70. Rock, C.L.; Flatt, S.W.; Barkai, H.S.; Pakiz, B.; Heath, D.D. A walnut-containing meal had similar effects on early satiety, CCK, and PYY, but attenuated the postprandial GLP-1 and insulin response compared to a nut-free control meal. Appetite 2017, 117, 51-57. [CrossRef]

71. Chen, C.Y.; Holbrook, M.; Duess, M.A.; Dohadwala, M.M.; Hamburg, N.M.; Asztalos, B.F.; Milbury, P.E.; Blumberg, J.B.; Vita, J.A. Effect of almond consumption on vascular function in patients with coronary artery disease: A randomized, controlled, cross-over trial. J. Nutr. 2015, 14, 61. [CrossRef]

72. Holt, R.R.; Yim, S.J.; Shearer, G.C.; Hackman, R.M.; Djurica, D.; Newman, J.W.; Shindel, A.W.; Keen, C.L. Effects of short-term walnut consumption on human microvascular function and its relationship to plasma epoxide content. J. Nutr. Biochem. 2015, 26, 1458-1466. [CrossRef]

73. Jung, H.; Chen, C.O.; Blumberg, J.B.; Kwak, H.K. The effect of almonds on vitamin E status and cardiovascular risk factors in Korean adults: A randomized clinical trial. Eur. J. Nutr. 2018, 57, 2069-2079. [CrossRef]

74. Moreira Alves, R.D.; Boroni Moreira, A.P.; Macedo, V.S.; Bressan, J.; de Cassia Goncalves Alfenas, R.; Mattes, R.; Brunoro Costa, N.M. High-oleic peanuts: New perspective to attenuate glucose homeostasis disruption and inflammation related obesity. Obesity 2014, 22, 1981-1988. [CrossRef]

75. Morgan, W.A.; Clayshulte, B.J. Pecans lower low-density lipoprotein cholesterol in people with normal lipid levels. J. Am. Diet. Assoc. 2000, 100, 312-318. [CrossRef]

76. Pearson, K.R.; Tey, S.L.; Gray, A.R.; Chisholm, A.; Brown, R.C. Energy compensation and nutrient displacement following regular consumption of hazelnuts and other energy-dense snack foods in non-obese individuals. Eur. J. Nutr. 2017, 56, 1255-1267. [CrossRef]

77. Reis, C.E.; Bordalo, L.A.; Rocha, A.L.; Freitas, D.M.; da Silva, M.V.; de Faria, V.C.; Martino, H.S.; Costa, N.M.; Alfenas, R.C. Ground roasted peanuts leads to a lower post-prandial glycemic response than raw peanuts. Nutr. Hosp. 2011, 26, 745-751. [CrossRef]

78. Abazarfard, Z.; Salehi, M.; Keshavarzi, S. The effect of almonds on anthropometric measurements and lipid profile in overweight and obese females in a weight reduction program: A randomized controlled clinical trial. J. Res. Med. Sci. 2014, 19, 457-464.

79. Sweazea, K.L.; Johnston , C.S.; Ricklefs , K.D.; Petersen, K.N. Almond supplementation in the absence of dietary advice significantly reduced C-reactive protein in subjects with type 2 diabetes. J. Funct. Foods 2014, 10, 252-259. [CrossRef] 
80. Damasceno, N.R.; Perez-Heras, A.; Serra, M.; Cofan, M.; Sala-Vila, A.; Salas-Salvado, J.; Ros, E. Crossover study of diets enriched with virgin olive oil, walnuts or almonds. Effects on lipids and other cardiovascular risk markers. Nutr. Metab. Cardiovasc. Dis. 2011, 21 (Suppl. S1), S14-S20. [CrossRef]

81. Jenkins, D.J.; Kendall, C.W.; Marchie, A.; Parker, T.L.; Connelly, P.W.; Qian, W.; Haight, J.S.; Faulkner, D.; Vidgen, E.; Lapsley, K.G.; et al. Dose response of almonds on coronary heart disease risk factors: Blood lipids, oxidized low-density lipoproteins, lipoprotein(a), homocysteine, and pulmonary nitric oxide: A randomized, controlled, crossover trial. Circulation 2002, 106, 1327-1332. [CrossRef]

82. Berryman, C.E.; West, S.G.; Fleming, J.A.; Bordi, P.L.; Kris-Etherton, P.M. Effects of daily almond consumption on cardiometabolic risk and abdominal adiposity in healthy adults with elevated LDL-cholesterol: A randomized controlled trial. J. Am. Heart Assoc. 2015, 4, e000993. [CrossRef]

83. Sabate, J.; Haddad, E.; Tanzman, J.S.; Jambazian, P.; Rajaram, S. Serum lipid response to the graduated enrichment of a Step I diet with almonds: A randomized feeding trial. Am. J. Clin. Nutr. 2003, 77, 1379-1384. [CrossRef]

84. Hollis, J.; Mattes, R. Effect of chronic consumption of almonds on body weight in healthy humans. Br. J. Nutr. 2007, 98, 651-656. [CrossRef]

85. Spiller, G.A.; Jenkins, D.A.; Bosello, O.; Gates, J.E.; Cragen, L.N.; Bruce, B. Nuts and plasma lipids: An almond-based diet lowers LDL-C while preserving HDL-C. Am. J. Coll. Nutr. 1998, 17, 285-290. [CrossRef]

86. Li, S.C.; Liu, Y.H.; Liu, J.F.; Chang, W.H.; Chen, C.M.; Chen, C.Y. Almond consumption improved glycemic control and lipid profiles in patients with type 2 diabetes mellitus. Metabolism 2011, 60, 474-479. [CrossRef]

87. Mazidi, M.; Rezaie, P.; Ferns, G.A.; Gao, H.K. Impact of different types of tree nut, peanut, and soy nut consumption on serum C-reactive protein (CRP): A systematic review and meta-analysis of randomized controlled clinical trials. Medicine 2016, 95, e5165. [CrossRef]

88. Viguiliouk, E.; Kendall, C.W.; Blanco Mejia, S.; Cozma, A.I.; Ha, V.; Mirrahimi, A.; Jayalath, V.H.; Augustin, L.S.; Chiavaroli, L.; Leiter, L.A.; et al. Effect of tree nuts on glycemic control in diabetes: A systematic review and meta-analysis of randomized controlled dietary trials. PLoS ONE 2014, 9, e103376. [CrossRef]

89. Blanco Mejia, S.; Kendall, C.W.; Viguiliouk, E.; Augustin, L.S.; Ha, V.; Cozma, A.I.; Mirrahimi, A.; Maroleanu, A.; Chiavaroli, L.; Leiter, L.A.; et al. Effect of tree nuts on metabolic syndrome criteria: A systematic review and meta-analysis of randomised controlled trials. BMJ Open 2014, 4, e004660. [CrossRef]

90. Bamberger, C.; Rossmeier, A.; Lechner, K.; Wu, L.; Waldmann, E.; Stark, R.G.; Altenhofer, J.; Henze, K.; Parhofer, K.G. A Walnut-Enriched Diet Reduces Lipids in Healthy Caucasian Subjects, Independent of Recommended Macronutrient Replacement and Time Point of Consumption: A Prospective, Randomized, Controlled Trial. Nutrients 2017, 9, 1097. [CrossRef]

91. Barbour, J.A.; Howe, P.R.; Buckley, J.D.; Bryan, J.; Coates, A.M. Effect of 12 Weeks High Oleic Peanut Consumption on Cardio-Metabolic Risk Factors and Body Composition. Nutrients 2015, 7, 7381-7398. [CrossRef]

92. Chen, C.M.; Liu, J.F.; Li, S.C.; Huang, C.L.; Hsirh, A.T.; Weng, S.F.; Chang, M.L.; Li, H.T.; Mohn, E.; Chen, C.O. Almonds ameliorate glycemic control in Chinese patients with better controlled type 2 diabetes: A randomized, crossover, controlled feeding trial. Nutr. Metab. 2017, 14, 51. [CrossRef]

93. Cohen, A.E.; Johnston, C.S. Almond ingestion at mealtime reduces postprandial glycemia and chronic ingestion reduces hemoglobin $\mathrm{A}(1 \mathrm{c})$ in individuals with well-controlled type 2 diabetes mellitus. Metabolism 2011, 60, 1312-1317. [CrossRef]

94. Damavandi, R.D.; Eghtesadi, S.; Shidfar, F.; Heydari, I.; Foroushani, A.R. Effects of hazelnuts consumption on fasting blood sugar and lipoproteins in patients with type 2 diabetes. J. Res. Med. Sci. 2013, 18, 314-321.

95. Gulati, S.; Misra, A.; Pandey, R.M.; Bhatt, S.P.; Saluja, S. Effects of pistachio nuts on body composition, metabolic, inflammatory and oxidative stress parameters in Asian Indians with metabolic syndrome: A 24-wk, randomized control trial. Nutrition 2014, 30, 192-197. [CrossRef]

96. Hernandez-Alonso, P.; Salas-Salvado, J.; Baldrich-Mora, M.; Juanola-Falgarona, M.; Bullo, M. Beneficial effect of pistachio consumption on glucose metabolism, insulin resistance, inflammation, and related metabolic risk markers: A randomized clinical trial. Diabetes Care 2014, 37, 3098-3105. [CrossRef]

97. Jenkins, D.J.; Kendall, C.W.; Marchie, A.; Josse, A.R.; Nguyen, T.H.; Faulkner, D.A.; Lapsley, K.G.; Singer, W. Effect of almonds on insulin secretion and insulin resistance in nondiabetic hyperlipidemic subjects: A randomized controlled crossover trial. Metabolism 2008, 57, 882-887. [CrossRef] 
98. Kasliwal, R.R.; Bansal, M.; Mehrotra, R.; Yeptho, K.P.; Trehan, N. Effect of pistachio nut consumption on endothelial function and arterial stiffness. Nutrition 2015, 31, 678-685. [CrossRef]

99. Katz, D.L.; Davidhi, A.; Ma, Y.; Kavak, Y.; Bifulco, L.; Njike, V.Y. Effects of walnuts on endothelial function in overweight adults with visceral obesity: A randomized, controlled, crossover trial. Am. J. Coll. Nutr. 2012, 31, 415-423. [CrossRef]

100. Lee, Y.J.; Nam, G.E.; Seo, J.A.; Yoon, T.; Seo, I.; Lee, J.H.; Im, D.; Bahn, K.N.; Jeong, S.A.; Kang, T.S.; et al. Nut consumption has favorable effects on lipid profiles of Korean women with metabolic syndrome. Nutr. Res. 2014, 34, 814-820. [CrossRef]

101. Li, Z.; Song, R.; Nguyen, C.; Zerlin, A.; Karp, H.; Naowamondhol, K.; Thames, G.; Gao, K.; Li, L.; Tseng, C.H.; et al. Pistachio nuts reduce triglycerides and body weight by comparison to refined carbohydrate snack in obese subjects on a 12-week weight loss program. J. Am. Coll. Nutr. 2010, 29, 198-203. [CrossRef]

102. Lovejoy, J.C.; Most, M.M.; Lefevre, M.; Greenway, F.L.; Rood, J.C. Effect of diets enriched in almonds on insulin action and serum lipids in adults with normal glucose tolerance or type 2 diabetes. Am. J. Clin. Nutr. 2002, 76, 1000-1006. [CrossRef]

103. Ma, Y.; Njike, V.Y.; Millet, J.; Dutta, S.; Doughty, K.; Treu, J.A.; Katz, D.L. Effects of walnut consumption on endothelial function in type 2 diabetic subjects: A randomized controlled crossover trial. Diabetes Care 2010, 33, 227-232. [CrossRef]

104. McKay, D.L.; Eliasziw, M.; Chen, C.Y.O.; Blumberg, J.B. A Pecan-Rich Diet Improves Cardiometabolic Risk Factors in Overweight and Obese Adults: A Randomized Controlled Trial. Nutrients 2018, 10, 339. [CrossRef]

105. Mohan, V.; Gayathri, R.; Jaacks, L.M.; Lakshmipriya, N.; Anjana, R.M.; Spiegelman, D.; Jeevan, R.G.; Balasubramaniam, K.K.; Shobana, S.; Jayanthan, M.; et al. Cashew Nut Consumption Increases HDL Cholesterol and Reduces Systolic Blood Pressure in Asian Indians with Type 2 Diabetes: A 12-Week Randomized Controlled Trial. Nutr. J. 2018, 148, 63-69. [CrossRef]

106. Mukuddem-Petersen, J.; Stonehouse Oosthuizen, W.; Jerling, J.C.; Hanekom, S.M.; White, Z. Effects of a high walnut and high cashew nut diet on selected markers of the metabolic syndrome: A controlled feeding trial. Br. J. Nutr. 2007, 97, 1144-1153. [CrossRef]

107. Mullner, E.; Plasser, E.; Brath, H.; Waldschutz, W.; Forster, E.; Kundi, M.; Wagner, K.H. Impact of polyunsaturated vegetable oils on adiponectin levels, glycaemia and blood lipids in individuals with type 2 diabetes: A randomised, double-blind intervention study. J. Hum. Nutr. Diet 2014, 27, 468-478. [CrossRef]

108. Njike, V.Y.; Ayettey, R.; Petraro, P.; Treu, J.A.; Katz, D.L. Walnut ingestion in adults at risk for diabetes: Effects on body composition, diet quality, and cardiac risk measures. BMJ Open Diabetes Res. Care 2015, 3, e000115. [CrossRef]

109. Parham, M.; Heidari, S.; Khorramirad, A.; Hozoori, M.; Hosseinzadeh, F.; Bakhtyari, L.; Vafaeimanesh, J. Effects of pistachio nut supplementation on blood glucose in patients with type 2 diabetes: A randomized crossover trial. Rev. Diabet. Stud. 2014, 11, 190-196. [CrossRef]

110. Sauder, K.A.; McCrea, C.E.; Ulbrecht, J.S.; Kris-Etherton, P.M.; West, S.G. Effects of pistachios on the lipid/lipoprotein profile, glycemic control, inflammation, and endothelial function in type 2 diabetes: A randomized trial. Metabolism 2015, 64, 1521-1529. [CrossRef]

111. Tapsell, L.C.; Lonergan, M.; Batterham, M.J.; Neale, E.P.; Martin, A.; Thorne, R.; Deane, F.; Peoples, G. Effect of interdisciplinary care on weight loss: A randomised controlled trial. BMJ Open Diabetes Res. Care 2017, 7, e014533. [CrossRef]

112. Tapsell, L.C.; Batterham, M.J.; Teuss, G.; Tan, S.Y.; Dalton, S.; Quick, C.J.; Gillen, L.J.; Charlton, K.E. Long-term effects of increased dietary polyunsaturated fat from walnuts on metabolic parameters in type II diabetes. Eur. J. Clin. Nutr. 2009, 63, 1008-1015. [CrossRef]

113. Wang, X.; Li, Z.; Liu, Y.; Lv, X.; Yang, W. Effects of pistachios on body weight in Chinese subjects with metabolic syndrome. Nutr. J. 2012, 11, 20. [CrossRef]

114. Wien, M.A.; Sabate, J.M.; Ikle, D.N.; Cole, S.E.; Kandeel, F.R. Almonds vs complex carbohydrates in a weight reduction program. Int. J. Obes. Relat. Metab. Disord. 2003, 27, 1365-1372. [CrossRef]

115. Wien, M.; Oda, K.; Sabate, J. A randomized controlled trial to evaluate the effect of incorporating peanuts into an American Diabetes Association meal plan on the nutrient profile of the total diet and cardiometabolic parameters of adults with type 2 diabetes. Nutr. J. 2014, 13, 10. [CrossRef] 
116. Wu, H.; Pan, A.; Yu, Z.; Qi, Q.; Lu, L.; Zhang, G.; Yu, D.; Zong, G.; Zhou, Y.; Chen, X.; et al. Lifestyle counseling and supplementation with flaxseed or walnuts influence the management of metabolic syndrome. Nutr. J. 2010, 140, 1937-1942. [CrossRef]

117. Wu, L.; Piotrowski, K.; Rau, T.; Waldmann, E.; Broedl, U.C.; Demmelmair, H.; Koletzko, B.; Stark, R.G.; Nagel, J.M.; Mantzoros, C.S.; et al. Walnut-enriched diet reduces fasting non-HDL-cholesterol and apolipoprotein B in healthy Caucasian subjects: A randomized controlled cross-over clinical trial. Metabolism 2014, 63, 382-391. [CrossRef]

118. Colpo, E.; Dalton, D.A.V.C.; Reetz, L.G.; Duarte, M.M.; Farias, I.L.; Meinerz, D.F.; Mariano, D.O.; Vendrusculo, R.G.; Boligon, A.A.; Dalla Corte, C.L.; et al. Brazilian nut consumption by healthy volunteers improves inflammatory parameters. Nutrition 2014, 30, 459-465. [CrossRef]

119. Rajaram, S.; Connell, K.M.; Sabate, J. Effect of almond-enriched high-monounsaturated fat diet on selected markers of inflammation: A randomised, controlled, crossover study. Br. J. Nutr. 2010, 103, 907-912. [CrossRef]

120. Bakhtiary, A.; Yassin, Z.; Hanachi, P.; Rahmat, A.; Ahmad, Z.; Jalali, F. Effects of soy on metabolic biomarkers of cardiovascular disease in elderly women with metabolic syndrome. Arch. Iran. Med. 2012, 15, 462-468.

121. Reverri, E.J.; LaSalle, C.D.; Franke, A.A.; Steinberg, F.M. Soy provides modest benefits on endothelial function without affecting inflammatory biomarkers in adults at cardiometabolic risk. Mol. Nutr. Food Res. 2015, 59, 323-333. [CrossRef] [PubMed]

122. Azadbakht, L.; Kimiagar, M.; Mehrabi, Y.; Esmaillzadeh, A.; Padyab, M.; Hu, F.B.; Willett, W.C. Soy inclusion in the diet improves features of the metabolic syndrome: A randomized crossover study in postmenopausal women. Am. J. Clin. Nutr. 2007, 85, 735-741. [CrossRef]

123. Brennan, A.M.; Sweeney, L.L.; Liu, X.; Mantzoros, C.S. Walnut consumption increases satiation but has no effect on insulin resistance or the metabolic profile over a 4-day period. Obesity 2010, 18, 1176-1182. [CrossRef] [PubMed]

124. Aronis, K.N.; Vamvini, M.T.; Chamberland, J.P.; Sweeney, L.L.; Brennan, A.M.; Magkos, F.; Mantzoros, C.S. Short-term walnut consumption increases circulating total adiponectin and apolipoprotein A concentrations, but does not affect markers of inflammation or vascular injury in obese humans with the metabolic syndrome: Data from a double-blinded, randomized, placebo-controlled study. Metabolism 2012, 61, 577-582. [CrossRef] [PubMed]

125. Ros, E.; Núñez, I.; Pérez-Heras, A.; Serra, M.; Gilabert, R.; Casals, E.; Deulofeu, R. A walnut diet improves endothelial function in hypercholesterolemic subjects: A randomized crossover trial. Circulation 2004, 109, 1609. [CrossRef] [PubMed]

126. Holligan, S.; West, S.; Gebauer, S.; Kay, C.; Kris-Etherton, P. A Moderate-Fat Diet with Pistachios Lowers Small-Dense LDL and Improves Markers of Insulin Sensitivity in Subjects with Moderately-Elevated Cholesterol Levels. FASEB J. 2013, 27, 1057.1053.

127. Schutte, A.E.; Van Rooyen, J.M.; Huisman, H.W.; Mukuddem-Petersen, J.; Oosthuizen, W.; Hanekom, S.M.; Jerling, J.C. Modulation of baroreflex sensitivity by walnuts versus cashew nuts in subjects with metabolic syndrome. Am. J. Hypertens. 2006, 19, 629-636. [CrossRef]

128. Anderson, A.; Anderson, M.; Jacobson, J.; Popko, M.; Young, J.; Limburg, P.; Wilson, T. Metabolic Effects of Bedtime Pistachio Consumption for 6 weeks in Overweight Persons. FASEB J. 2013, 27, 1072-1120.

129. Somerset, S.M.; Graham, L.; Markwell, K. Isoenergetic replacement of dietary saturated with monounsaturated fat via macadamia nuts enhances endothelial function in overweight subjects. E Spen Eur. E J. Clin. Nutr. Metab. 2013, 8, e113-e119. [CrossRef]

130. Sauder, K.; Mccrea, C.; Kris-Etherton, P.; Ulbrecht, J.; West, S. Effect of pistachios on lipids, lipoproteins, glucose metabolism, and insulin sensitivity in type 2 diabetes. FASEB J. 2013, 27. [CrossRef]

131. Jenkins, D.J.; Kendall, C.W.; Banach, M.S.; Srichaikul, K.; Vidgen, E.; Mitchell, S.; Parker, T.; Nishi, S.; Bashyam, B.; de Souza, R.; et al. Nuts as a replacement for carbohydrates in the diabetic diet. Diabetes Care 2011, 34, 1706-1711. [CrossRef] [PubMed]

132. Damavandi, R.D. The effects of cashew consumption on serum glucose, insulin and lipoprotein in type 2 diabetic patients Iran. J. Endocrinol. Metab. 2012, 14, 325-334.

133. Musa-Veloso, K.; Paulionis, L.; Poon, T.; Lee, H.Y. The effects of almond consumption on fasting blood lipid levels: A systematic review and meta-analysis of randomised controlled trials. J. Nutr. Sci. 2016, 5 , e34. [CrossRef] [PubMed] 
134. Perna, S.; Giacosa, A.; Bonitta, G.; Bologna, C.; Isu, A.; Guido, D.; Rondanelli, M. Effects of Hazelnut Consumption on Blood Lipids and Body Weight: A Systematic Review and Bayesian Meta-Analysis. Nutrients 2016, 8, 747. [CrossRef] [PubMed]

135. Del Gobbo, L.C.; Falk, M.C.; Feldman, R.; Lewis, K.; Mozaffarian, D. Effects of tree nuts on blood lipids, apolipoproteins, and blood pressure: Systematic review, meta-analysis, and dose-response of 61 controlled intervention trials. Am. J. Clin. Nutr. 2015, 102, 1347-1356. [CrossRef] [PubMed]

136. Sabate, J.; Oda, K.; Ros, E. Nut consumption and blood lipid levels: A pooled analysis of 25 intervention trials. Arch. Intern. Med. 2010, 170, 821-827. [CrossRef]

137. Phung, O.J.; Makanji, S.S.; White, C.M.; Coleman, C.I. Almonds have a neutral effect on serum lipid profiles: A meta-analysis of randomized trials. J. Am. Diet. Assoc. 2009, 109, 865-873. [CrossRef]

138. Kurlandsky DR, S.K. Cardioprotective effects of chocolate and almond consumption in healthy women. Nutr. Res. 2006, 26, 509-516. [CrossRef]

139. Tamizifar, B.; Rismankarzadeh, M.; Vosoughi, A.A.; Rafieeyan, M.; Tamizifar, B.; Aminzade, A. A low-dose almond-based diet decreases LDL-C while preserving HDL-C. Arch. Iran. Med. 2005, 8, 45-51.

140. Kim, R.J.; Wang, L.; Worley, S.; Leonard, D. Nut consumption and metabolic syndrome in US adolescents. Public Health Nutr. 2018, 21, 3245-3252. [CrossRef]

141. Li, Y.; Zhao, L.; Yu, D.; Wang, Z.; Ding, G. Metabolic syndrome prevalence and its risk factors among adults in China: A nationally representative cross-sectional study. PLoS ONE 2018, 13, e0199293. [CrossRef] [PubMed]

142. Relja, A.; Miljkovic, A.; Gelemanovic, A.; Boskovic, M.; Hayward, C.; Polasek, O.; Kolcic, I. Nut Consumption and Cardiovascular Risk Factors: A Cross-Sectional Study in a Mediterranean Population. Nutrients 2017, 9, 1296. [CrossRef] [PubMed]

143. Jaceldo-Siegl, K.; Haddad, E.; Oda, K.; Fraser, G.E.; Sabate, J. Tree nuts are inversely associated with metabolic syndrome and obesity: The Adventist health study-2. PLoS ONE 2014, 9, e85133. [CrossRef] [PubMed]

144. Ibarrola-Jurado, N.; Bullo, M.; Guasch-Ferre, M.; Ros, E.; Martinez-Gonzalez, M.A.; Corella, D.; Fiol, M.; Warnberg, J.; Estruch, R.; Roman, P.; et al. Cross-sectional assessment of nut consumption and obesity, metabolic syndrome and other cardiometabolic risk factors: The PREDIMED study. PLoS ONE 2013, 8 , e57367. [CrossRef]

145. O’Neil, C.E.; Keast, D.R.; Nicklas, T.A.; Fulgoni, V.L., 3rd. Nut consumption is associated with decreased health risk factors for cardiovascular disease and metabolic syndrome in U.S. adults: NHANES 1999-2004. J. Am. Coll. Nutr. 2011, 30, 502-510. [CrossRef]

146. Lutsey, P.L.; Steffen, L.M.; Stevens, J. Dietary intake and the development of the metabolic syndrome: The Atherosclerosis Risk in Communities study. Circulation 2008, 117, 754-761. [CrossRef]

147. Hassannejad, R.; Mohammadifard, N.; Kazemi, I.; Mansourian, M.; Sadeghi, M.; Roohafza, H.; Sarrafzadegan, N. Long-term nuts intake and metabolic syndrome: A 13-year longitudinal population-based study. Clin. Nutr. 2019, 38, 1246-1252. [CrossRef]

148. Hosseinpour-Niazi, S.; Hosseini, S.; Mirmiran, P.; Azizi, F. Prospective Study of Nut Consumption and Incidence of Metabolic Syndrome: Tehran Lipid and Glucose Study. Nutrients 2017, 9, 1056. [CrossRef]

149. Fernandez-Montero, A.; Bes-Rastrollo, M.; Beunza, J.J.; Barrio-Lopez, M.T.; de la Fuente-Arrillaga, C.; Moreno-Galarraga, L.; Martinez-Gonzalez, M.A. Nut consumption and incidence of metabolic syndrome after 6-year follow-up: The SUN (Seguimiento Universidad de Navarra, University of Navarra Follow-up) cohort. Public Health Nutr. 2013, 16, 2064-2072. [CrossRef]

150. Baik, I.; Lee, M.; Jun, N.R.; Lee, J.Y.; Shin, C. A healthy dietary pattern consisting of a variety of food choices is inversely associated with the development of metabolic syndrome. Nutr. Res. Pract. 2013, 7, 233-241. [CrossRef]

(C) 2019 by the authors. Licensee MDPI, Basel, Switzerland. This article is an open access article distributed under the terms and conditions of the Creative Commons Attribution (CC BY) license (http://creativecommons.org/licenses/by/4.0/). 